\title{
From Valeriana officinalis to cancer therapy: the success of a bio-sourced compound
}

\author{
Malik Hamaidia ${ }^{(1,2,3)}$, Pierre-Yves Barez ${ }^{(2,3)}$, Alexandre Carpentier ${ }^{(2,3)}$, Simon \\ Lebecque $^{(1,2)}$, Krystian Miazek ${ }^{(1,2)}$, Aman Paul ${ }^{(1,2)}$, Sathya Neelature Sriramareddy ${ }^{(2,3)}$, \\ Bernard Staumont ${ }^{(2,3)}$, Sabine Danthine ${ }^{(2)}$, Magali Deleu ${ }^{(2)}$, Michel Frederich ${ }^{(4)}$, Edwin \\ De Pauw ${ }^{(5)}$, Pierre Delaplace ${ }^{(2)}$, Frank Delvigne ${ }^{(2)}$, Dorothée Goffin ${ }^{(2)}$, Marc Ongena ${ }^{(2)}$, \\ Bernard Duysinx ${ }^{(6)}$, Renaud Louis ${ }^{(6)}$, Jean-Philippe Cosse ${ }^{(2,3)}$, Luc Willems ${ }^{(2,3)}$ \\ (1) University of Liège - Gembloux Agro-Bio Tech. TERRA. AgricultureIsLife. Passage des Déportés, 2. BE-5030 Gembloux \\ (Belgium). \\ (2) University of Liège - Gembloux Agro-Bio Tech. Agrobiochem. Passage des Déportés, 2. BE-5030 Gembloux (Belgium). \\ E-mail: luc.willems@ulg.ac.be \\ (3) University of Liège. Molecular and cellular epigenetics. GIGA. Avenue de l'Hôpital, 1. BE-4000 Sart-Tilman (Belgium). \\ (4) University of Liège. CIRM. Avenue de l'Hôpital, 1. BE-4000 Sart-Tilman (Belgium). \\ (5) University of Liège. Mass Spectrometry Laboratory. Allée de la Chimie, 3. BE-4000 Liège (Belgium). \\ (6) University Hospital Center of Liège (CHU). Pneumology. Avenue de l'Hôpital, 1. BE-4000 Sart-Tilman (Belgium).
}

Received on October 20, 2014: accepted on October 12, 2015.

Introduction. Over the centuries, bio-sourced compounds isolated from plants, insects and microorganisms have been a potent source of drugs for the treatment of human diseases.

Literature. Bio-sourced extracts offer a wide diversity of compounds with a large number of potentially beneficial effects in humans. Serendipity has frequently played a key role in the discovery of new medicines. The canonical discovery of penicillin required both chance and a prepared mind to understand and exploit its potential for the treatment of human infections. Nowadays, most anti-cancer drugs currently in clinical use were at least partly discovered by a "fortunate happenstance".

Conclusions. In this review, we recapitulate the story of one of these compounds, 2-propylpentanoic acid, derived from the Valeriana officinalis flowering plant and its path to validation as a cancer treatment.

Keywords. Valeriana officinalis, medicinal properties, epilepsy, chromatin, gene expression, neoplasms.

De la valériane au traitement du cancer : le succès d'un composé biosourcé

Introduction. Depuis plusieurs siècles, des composés extraits de plantes, d'insectes ou de micro-organismes ont été utilisés comme remèdes pour soigner diverses maladies humaines.

Littérature. Les substances naturelles peuvent être à l'origine de composés ayant des effets bénéfiques sur la santé humaine. De manière surprenante, la sérendipité a fréquemment joué un rôle majeur dans le développement de nouveaux médicaments. Par exemple, la découverte de la pénicilline par Fleming a nécessité une combinaison de chance, de curiosité et d'intuition permettant son exploitation dans le traitement des maladies infectieuses. De plus, plusieurs agents anti-cancéreux couramment utilisés en clinique ont été mis en évidence suite à un heureux concours de circonstances.

Conclusions. Cette revue met en relief les différentes étapes ayant permis le développement de 1'acide 2-propylpentanoïque à partir de la valériane jusqu'à son utilisation dans le traitement contre le cancer.

Mots-clés. Valeriana officinalis, propriété pharmacologique, épilepsie, chromatine, expression des gènes, néoplasme.

\section{INTRODUCTION}

The Oxford dictionary (http://www.oed.com/) defines serendipity as "the faculty of making happy and unexpected discoveries by accident". During human history, the combination of serendipity and advances in biochemistry fostered the discovery of medicines from bio-sourced materials. For example, the discovery by Pasteur of the chicken cholera vaccine had a strong element of chance (Smith, 2012). Due to a period of 
holidays, his assistant neglected to prepare a fresh batch of bacteria. When returning to work after a few weeks, the solution was no longer infectious, indicating that the inoculum had been ruined. The perspicacity of Pasteur then triggered an experiment previously described by Jenner with the smallpox vaccine. Pasteur discovered that chickens previously injected with the old batch of bacteria were protected from cholera. Another famous example of chance discovery is penicillin. In 1928, bacteriologist Alexander Fleming discovered that the Penicillium fungus having contaminated his Petri dishes produced a powerful antibiotic (Bentley, 2005). In fact, the ancient Egyptians, the Chinese, and Indians of Central America already used molds and fermented materials for the treatment of infected wounds (Forrest, 1982). However, they did not establish a biological connection between the antibacterial properties of mold and the treatment of diseases. In 1940, Ernst Chain and Edward Penley Abraham developed a freezedrying protocol to concentrate penicillin. A further purification step based on absorption on activated charcoal was further provided by Christian De Duve (Ligon, 2004). These successive developments were vital early steps, in what would become one of the most popular antibiotics to treat bacterial infections, leading ultimately to the emergence of GlaxoSmithKline.

Besides serendipity, a discovery also needs understanding of the mechanisms, transmission of knowledge and technical development. Today, thanks to fortunate happenstance, several bio-active molecules have been isolated and are currently in clinical use. A recent review estimated that $24 \%$ of all medicines available on the market (including antibiotics, psychotropic drugs and anti-cancer compounds) were at least partly discovered serendipitously (HargraveThomas et al., 2012). In fact, this was the case for more than one third of all cancer medicines. Among them, a short chain fatty acid called 2-propylpentanoic acid, has attracted increased attention over the course of several centuries. 2-propylpentanoic acid has been and is still in clinical use to treat neurologic disorders (e.g. epilepsy, schizophrenia, bipolar disorders). Due to its bioavailability and acceptable toxicity, 2-propylpentanoic acid has also become one of the most promising drugs for cancer treatment due to its ability to modulate epigenetics. This review highlights the milestones that led to the use of 2-propylpentanoic acid in the treatment of human diseases.

\section{VALERIANA OFFICINALIS: THE ROOTS OF SUCCESS}

The story began more than 2,000 years ago with a flowering plant called Valeriana officinalis, also known as "All-heal" (English), "Baldrian" (German), "Herbe aux chats" (French). The dried rhizome and roots of $V$. officinalis are still used in traditional medicine for the treatment of a broad variety of disorders such as insomnia, headaches, gastro-intestinal problems, heart palpitations and urinary tract infections (World Health Organization, 1999). The name "Valeriana" is believed to derive from the Latin word "valere" that means "healthy, courageous, strong, powerful or brave". This Latin word also refers to a famous Roman Emperor called Valerian the Elder from 253 to 259. The word "officinalis" derives from "Officina", a Medieval Latin word referring to monastery pharmacy and apothecaries shops. The adjective "officinalis" is used in botanical Latin to indicate its medicinal use. As a species of the Valerianaceae family, V. officinalis is a tall perennial herb of about $150 \mathrm{~cm}$ whose underground portion consists of a vertical rhizome bearing numerous rootlets and one or more stolons (Figure 1). The inflorescence consists of racemes of cymes whose flowers are calyx 5-lobed, pale pink to white. Valeriana species are still cultivated for medicinal purposes in North of Europe especially in Germany, The Netherlands, Belgium and France (World Health Organization, 1999). The cultivation and therapeutic uses of $V$. officinalis in Europe are approved by the European Medicines Agency. The chemical composition of valerian roots depends on the growing conditions as well as the subspecies (ssp. officinalis, ssp. collina Nyman and ssp. sabucifolia). Chemical characterization of these subspecies by high liquid performance chromatography and gas chromatography allowed for the identification of a series of compounds including essential oils, their sesquiterpenoid derivatives and alkaloids (Figure 1) (Upton, 1999; Navarrete et al., 2006; Pharmacopoeia, 2014). Over the centuries, traditional medicine used crude valerian extracts containing these molecules without fully understanding the mechanisms involved, apparently with some successful therapeutic responses.

The next step arose from the property of one of these compounds, valeric acid (or pentanoic acid), a short chain fatty acid and its derivatives. Valeric acid has an unpleasant odor like other short chain fatty acids from the gut such as butyric acid. In contrast, esters of valeric acid are volatile and widely used in perfumes and cosmetics. Another key property of valeric acid results from its structure, which combines a hydrophobic hydrocarbon chain with a carboxylic acid group (Figure 1). Due to the low hydrophobic nature of the alkyl chain, valeric acid is miscible in water and can be used to solubilize other compounds. Analogs of valeric acid can be obtained by oxidation of primary alcohols and aldehydes with potassium permanganate or sodium chlorite. In 1882, chemist Beverly Burton successfully synthesized mono- and dipropylethyl acetoacetate by using propyl iodide and ethyl acetoacetate (Burton, 1882). In a milestone paper 


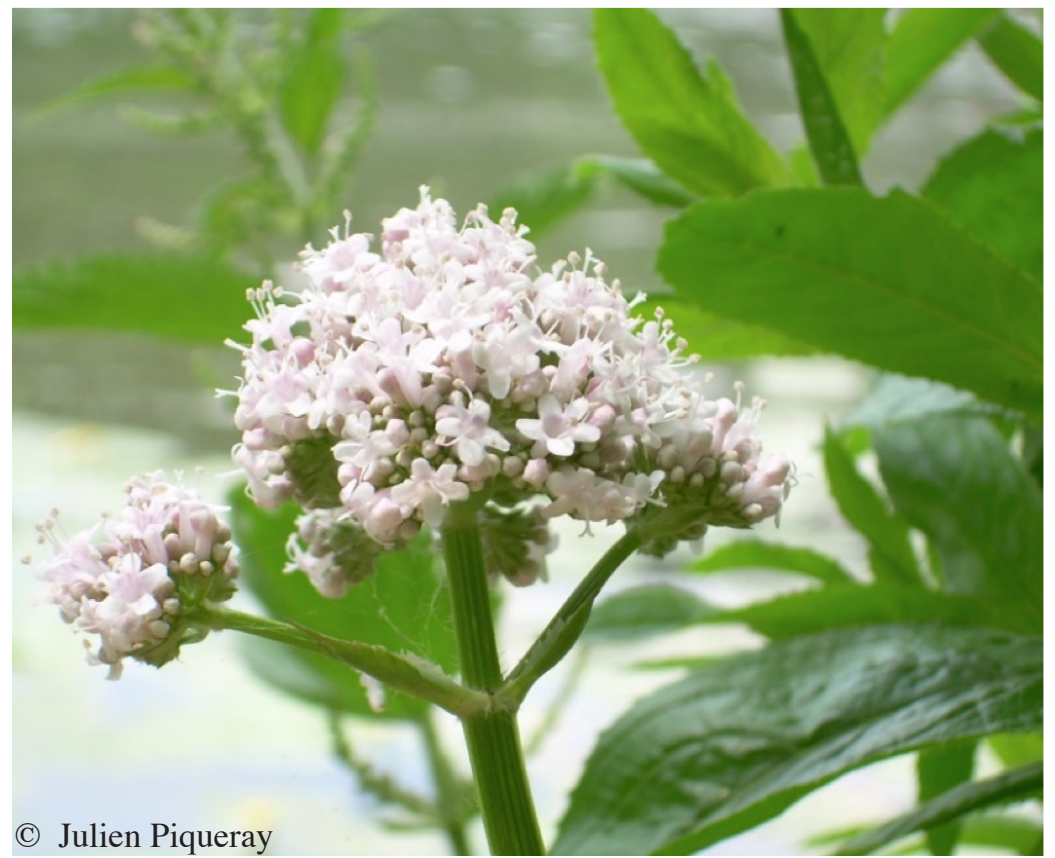<smiles>CC1=C2[C@@H](/C=C(\C)C(=O)O)CC[C@H](C)[C@H]2CC1</smiles>

Valerenic acid<smiles>CCCCC(=O)O</smiles>

Valeric acid<smiles>Cc1cncc2c1CC[C@H]2C</smiles>

Actinidine<smiles>[R]OCC1=CO[C@@H](O[R])[C@@H]2C1=CC[C@@]21CO1</smiles>

Valepotriates

Figure 1. Chemical compounds isolated from Valeriana officinalis roots - Composés chimiques isolés à partir des racines de Valeriana officinalis.

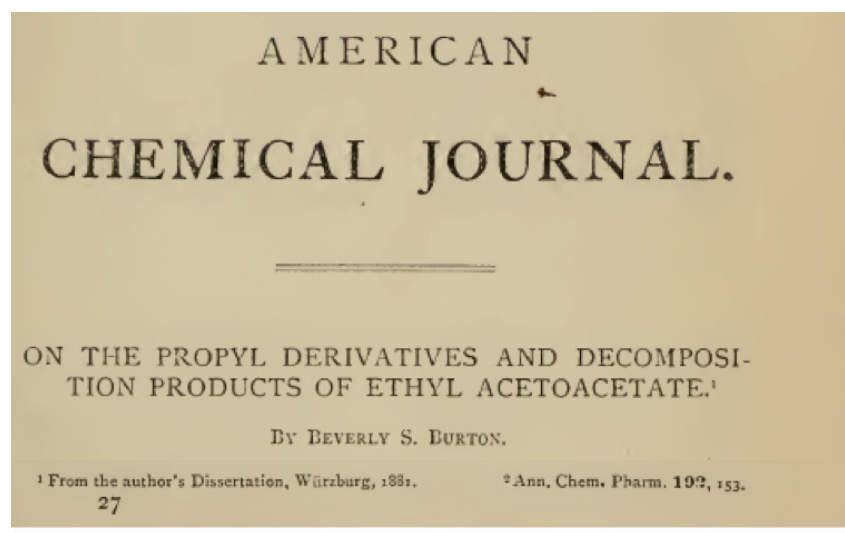<smiles>CCCC(CCC)(C(C)=O)C(=O)OCC</smiles>

dipropylethyl acetoacetate<smiles>CCCC(CCC)(C(C)=O)C(=O)O</smiles>

dipropyl- $\beta$-oxybutyric acid<smiles>CCCC(CCC)C(C)=O</smiles>

dipropylacetone<smiles>CCCC(CCC)C(=O)O</smiles>

2-propylpentanoic acid
(Figure 2), Burton also obtained novel compounds by alkaline decomposition of dipropylethyl acetoacetate with acetic acid, acetone and betaoxybutyric acid. Among other products such as dipropylacetone and dipropyl- $\beta$-oxybutyric acid, 2-propylpentanoic acid had particularly interesting properties as an organic solvent soluble in water.

\section{2-PROPYLPENTANOIC ACID TO TREAT SEIZURE DISORDERS: A FORTUITOUS DISCOVERY}

In 1962, Pierre Eymard and colleagues were studying the anti-seizure activity of a series of khelline compounds in animal models (Meunier et al., 1963). They faced a major difficulty due to the insolubility of

Figure 2. Structure of compounds synthesized by Burton - Structure des molécules synthétisées par Burton.

Snapshot of the original paper published in 1882 by Burton: On the propyl derivatives and decomposition of ethylacetoacetate. American Chemical Journal, 3, 385-395. Burton synthesized dipropylethyl acetoacetate, dipropylacetone, dipropylbetaoxybutyric acid and 2-propylpentanoic acid - Instantané de l'article original publié en 1882 par Burton: On the propyl derivatives and decomposition of ethylacetoacetate. American Chemical Journal, 3, 385-395. Burton synthétisa le dipropyléthyl acétoacétate, le dipropylacétone, l'acide dipropylbetaoxybutyrique et l'acide 2-propylpentanö̈que. 
khelline in water as well as in other available solvents. Therefore, they used 2-propylpentanoic acid to dissolve methylene-cyano-norkhelline. Their experiment yielded promising results but also revealed that the control, 2-propylpentanoic acid without khelline, had an anticonvulsant property by itself. After evaluation of the therapeutic efficacy in human, 2-propylpentanoic acid was validated as an anti-epileptic drug in France in 1967 and approved by the US Food and Drug Administration in 1978 with different trade names: Depakote, Depakene (Abbott Laboratories in US \& Canada), Depakine and MicropakineLP (Sanofi-Aventis in Europe). 2-propylpentanoic acid then became the main treatment for mood disorders (e.g. epilepsy and bipolar depressive syndrome). In addition, 2-propylpentanoic acid demonstrated efficacy towards agitation and aggressive behavior in patients presenting mental disorders. Consistent with the correlation between the anticonvulsant action and reduced neuronal excitability, it was further demonstrated that 2-propylpentanoic acid raises the brain levels of $\gamma$-aminobutyric acid (GABA), a major inhibitor of neurotransmission in the brain (Simler et al., 1968; Godin et al., 1969; Loscher, 1981) (Figure 3). In neurons and glial cells, GABA is synthesized from glutamic acid by glutamate decarboxylase (GAD). GABA transaminase (GABA-T) then catalyzes transamination of GABA to succinic semi-aldehyde, which is further converted into succinic acid by succinic semi-aldehyde dehydrogenase thereby creating a negative feedback loop on GABA synthesis. 2-propylpentanoic acid inhibits GABA degradative enzymes such as GABA aminotransferase (GABA-T), succinic semi-aldehyde dehydrogenase (SSADH) and non-specific succinic semi-aldehyde reductase (Harvey et al., 1975). With a bioavailability greater than $80 \%$, 2-propylpentanoic acid is efficiently transferred to the peripheral blood upon oral administration. In the plasma, 2-propylpentanoic acid can either be free or protein-bound (Kishore et al., 2003). With a half-life of approximately 15-17 h, 2-propylpentanoic acid undergoes hepatic catabolism through hydroxylation, glucuronidation and mitochondrial $\beta$-oxidation (Figure 3).

Besides these remarkable properties, 2-propylpentanoic acid unfortunately increases the risk of neural tube defects and may be teratogenic during pregnancy (Nau et al., 1991). Other adverse effects mainly include moderate hepatotoxicity at high doses (Loscher, 2002).

\section{INHIBITION OF LYSINE ACETYLATION: A PROMISING TARGET FOR CANCER TREATMENT}

The next milestone issued from studies focusing on the molecular mechanisms of 2-propylpentanoic acid associated teratogenicity. A key observation was that 2-propylpentanoic acid stimulates the peroxisomeactivated receptor- $\delta$ (PPAR- $\delta$ ) at the transcriptional level without interfering with its ligand binding site (Gottlicher et al., 2001). PPARs are ligand-inducible nuclear receptors involved in lipid metabolism and glucose homeostasis. In the early 2000s, PPAR- $\delta$ expression was associated with inhibition of histone deacetylase (HDAC) activity by 2-propylpentanoic acid. By neutralizing or exposing the positively-charged lysine residues of $\mathrm{N}$-terminal of histone tails, histone acetyltransferases (HAT) and HDACs finely tune chromatin condensation (Figure 3). 2-propylpentanoic acid is a broad spectrum inhibitor affecting both class I (HDAC-1,-2,-3,-8) and II (HDAC-4,-5,-6,-7,-9 and -10) lysine deacetylases. The mechanism of inhibition includes the complexation by the carboxylic group of the zinc ion located in the HDAC catalytic pocket.

The availability of a pharmacological tool affecting gene expression opened new insights into the understanding of the epigenetic control of gene expression and DNA replication. Even more importantly, well-tolerated HDAC inhibitors such as 2-propylpentanoic acid also became therapeutic drugs for the treatment of cancer. Indeed, cancer cells are characterized by genetic alterations but also by inadequate expression of tumor suppressor genes. The model was successfully challenged in an animal model of leukemia and then further validated in humans (Achachi et al., 2005; Lezin et al., 2007; Vandermeers et al., 2009; Hubaux et al., 2010). Although the modes of action of 2-propylpentanoic acid still require clarification, the treatment appeared to be remarkably well tolerated. The anticancer mechanisms include activation of gene transcription, cell cycle arrest, modulation of intracellular signaling and of reactive oxygen species, induction of apoptosis and cell differentiation.

Among the clinical trials evaluating combinations between 2-propylpentanoic and other chemotherapeutic agents (Table 1), the most important are those tackling cancers without satisfactory treatment. One example is malignant mesothelioma (MM), a tumor of the pleura or the peritoneum, which is induced by exposure to asbestos fibers. Among $45 \mathrm{MM}$ relapsing patients treated with a combination of 2-propylpentanoic and doxorubicin (a DNA topoisomerase inhibitor), there were $16 \%$ partial responses and $9 \%$ stable diseases. Although still modest, these scores are nevertheless quite encouraging considering the lack of response in MM relapsing patients treated with doxorubicin alone. Although progression free survival is not prolonged, the new regimen has the remarkable ability to relieve pain and improve quality of life. Future challenges include the discovery of novel VPA-related compounds exhibiting a higher specificity towards MM tumors but 


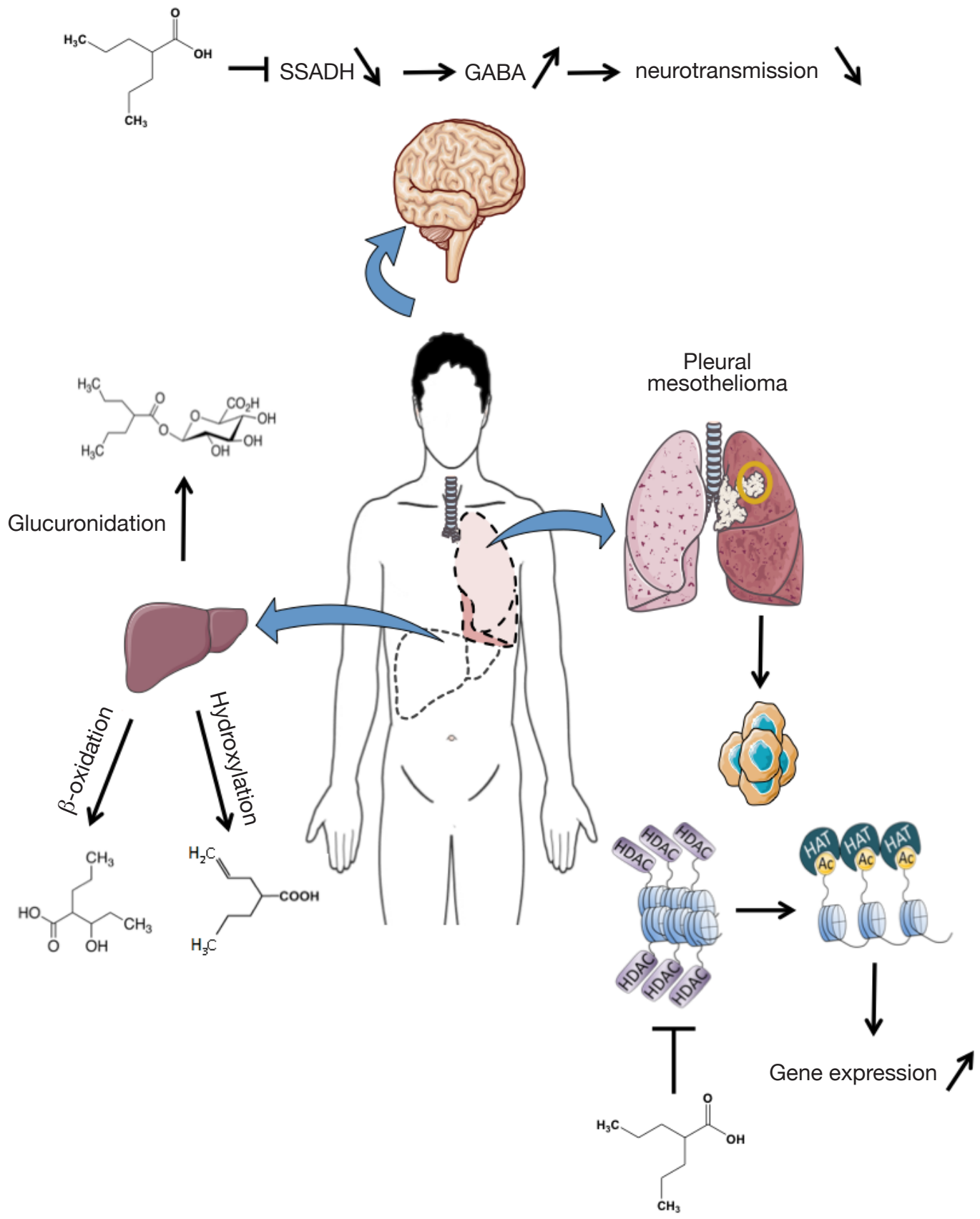

Figure 3. Metabolism and bioactivity of 2-propylpentanoic acid - Métabolisme et bioactivité de l'acide 2-propylpentanö̈que.

2-propylpentanoic acid is transformed by liver cells via three main metabolic pathways: glucuronidation by UDP-glucuronyl transferase (UPGT), hydroxylation by cytochrome P450 (CYP450) and $\beta$-oxidation in mitochondria by acetyl-CoA deshydrogenase. 2-propylpentanoic acid increases the brain levels of $\gamma$-aminobutyric acid (GABA) by inhibiting succinic semi-aldehyde dehydrogenase (SSADH). 2-propylpentanoic acid inhibits histone deacetylase (HDAC) and increases acetylation of lysine residues of histone tails. Acetylation of positively-charged amines of lysine residues by histone acetyltransferase (or HAT) reduces their affinity for DNA, decondensates chromatin and favors gene expression - L'acide 2-propylpentanö̈que est métabolisé par les cellules du foie via trois voies métaboliques : la glucuronidation par l'UDP-glucuronyl transférase (UPGT), l'hydroxylation par le cytochrome P450 (CYP450) et l'oxydation mitochondriale via l'acétyl-CoA déshydrogénase. L'acide 2-propylpentanö̈que augmente la concentration de l'acide $\gamma$-aminobutyrique (GABA) dans le cerveau en inhibant la semi-aldéhyde déhydrogénase succinique (SSADH). L'acide 2-propylpentanö̈que inhibe les désacétylases d'histone (HDAC) et augmente l'acétylation des résidus lysines des queues aminoterminales des histones. L'acétylation des groupements amines des lysines par l'histone acétyltransférase (HAT) réduit leur affinité pour l'ADN, décondense la chromatine et favorise l'expression génique. 
Table 1. Ongoing clinical trials of 2-propylpentanoic acid in cancer therapy - Essais cliniques évaluant l'effet de l'acide 2-propylpentanoïque dans le traitement du cancer.

\begin{tabular}{|c|c|c|c|c|}
\hline $\begin{array}{l}\text { Combination with } \\
\text { 2-propylpentanoic acid }\end{array}$ & Cytotoxic targets & Applications & Clinical trials & $\begin{array}{l}\text { Clinical Trial } \\
\text { Identifier }\end{array}$ \\
\hline Radiation & $\begin{array}{l}\text { Inhibition of HDAC } \\
\text { and DNA damages }\end{array}$ & $\begin{array}{l}\text { High grade sarcoma } \\
\text { Head and neck squamous cell } \\
\text { carcinoma } \\
\text { Non-metastatic prostate cancer } \\
\text { Rectal cancer } \\
\text { Non-Small-Cell lung cancer } \\
\text { Thyroid cancer }\end{array}$ & $\begin{array}{l}\text { Phase I } \\
\text { Phase II } \\
\text { Phase I } \\
\text { Phase I/II } \\
\text { Phase I/II } \\
\text { Phase II }\end{array}$ & $\begin{array}{l}\text { NCT01010958 } \\
\text { NCT01695122 } \\
\text { NCT00670046 } \\
\text { NCT01898104 } \\
\text { NCT01203735 } \\
\text { NCT01182285 }\end{array}$ \\
\hline $\begin{array}{l}\text { Camptothecin } \\
\text { Irinotecan } \\
\text { Karenitecin } \\
\text { Doxorubicine } \\
\text { Vindesine }\end{array}$ & $\begin{array}{l}\text { Topoisomerase } \\
\text { inhibitors }\end{array}$ & $\begin{array}{l}\text { Melanoma } \\
\text { Lung cancer } \\
\text { Malignant pleural mesothelioma }\end{array}$ & $\begin{array}{l}\text { Phase I/II } \\
\text { Phase II } \\
\text { Phase II }\end{array}$ & $\begin{array}{l}\text { NCT00358319 } \\
\text { NCT00759824 } \\
\text { NCT00634205 }\end{array}$ \\
\hline $\begin{array}{l}\text { Azacitidine } \\
\text { Decitabine }\end{array}$ & $\begin{array}{l}\text { DNA } \\
\text { methyltransferase } \\
\text { inhibitors }\end{array}$ & $\begin{array}{l}\text { Lung cancer } \\
\text { Leukemia } \\
\text { Ovarian cancer }\end{array}$ & $\begin{array}{l}\text { Phase I } \\
\text { Phase I } \\
\text { Phase I }\end{array}$ & $\begin{array}{l}\text { NCT00084981 } \\
\text { NCT00867672 } \\
\text { NCT00529022 }\end{array}$ \\
\hline Bevacizumab & $\begin{array}{l}\text { Angiogenesis inhibitor } \\
\text { (VEGF-A) }\end{array}$ & High grade gliomas & Phase II & NCT00879437 \\
\hline $\begin{array}{l}\text { All-trans retinoic acid } \\
\text { (ATRA) } \\
\text { Cytarabine }\end{array}$ & Cytosie arabinoside & Leukemia & Phase I/II & NCT00995332 \\
\hline Temsirolimus & $\begin{array}{l}\text { Mammalian target of } \\
\text { rapamycin (mTOR) }\end{array}$ & $\begin{array}{l}\text { Neuroblastoma } \\
\text { Tissue sarcoma }\end{array}$ & Phase I & NCT01204450 \\
\hline Hydralazine & $\begin{array}{l}\text { Smooth muscle } \\
\text { relaxant }\end{array}$ & Cervical cancer & Phase II & NCT00404326 \\
\hline
\end{tabular}

still preserving optimal tolerability. This perspective will be a major issue of the AgricultureIsLife program.

\section{CONCLUSIONS}

In this review, we have described the story of a compound, 2-propylpentanoic acid, starting from crude extracts of Valeriana officinalis used in traditional medicine and progressing to the demonstration of its ability to improve cancer treatment. This story reveals that the development of a useful bio-sourced drug requires the achievement of a series of milestones; include both an understanding of the biological mechanisms as well as technical developments where bottlenecks were bypassed thanks to chance, perspicacity and scientific curiosity.

\section{Acknowledgements}

This research was funded by the CARE AgricultureIsLife (University of Liège), the Synbiofor project of GxABT, the "ULg Fonds Spéciaux pour la Recherche", the "Action de Recherche Concertée Glyvir" of the "Communauté française de Belgique", the Télévie, the Interuniversity Attraction Poles (IAP) Program BELVIR initiated by the Belgian Science Policy Office, the Belgian Foundation against Cancer, the Sixth Research Framework Programme of the European Union (project INCA LSHC-CT-2005-018704), the "Neoangio" excellence program and the "Partenariat Public Privé" PPP INCA of the "Direction générale des Technologies, de la Recherche et de l'Énergie/DG06" of the Walloon government, the "Centre anticancéreux près ULg" $(\mathrm{CAC})$, the Fonds Léon Fredericq and the "Plan Cancer" of the "Service Public Fédéral". MH, KM and AP are PhD fellows of the "AgricultureIsLife" program of GxABT. BS, MD, MO and LW are members of the "Fonds National de la Recherche Scientifique" (FNRS). MH, PYB, AC, SL, $\mathrm{KH}, \mathrm{AP}, \mathrm{SR}$ and BS contributed equally. We thank Johan Wouters and Steve Lanners (University of Louvain, Namur, Belgium) for advice on chemical structures and Julien Piqueray ( University of Liège - Gembloux Agro-Bio Tech) for the picture of Valeriana officinalis.

\section{Bibliography}

Achachi A. et al., 2005. Valproate activates bovine leukemia virus gene expression, triggers apoptosis, and induces 
leukemia/lymphoma regression in vivo. PNAS, 102, 10309-10314.

Bentley R., 2005. The development of penicillin: genesis of a famous antibiotic. Perspect. Biol. Med., 48, 444-452.

Burton B., 1882. On the propyl derivatives and decomposition of ethyl-acetoacetate. Am. Chem. J., 3, 385-395.

Forrest R.D., 1982. Development of wound therapy from the Dark Ages to the present. J. R. Soc. Med., 75, 268-273.

Godin Y., Heiner L., Mark J. \& Mandel P., 1969. Effects of DI-n-propylacetate, and anticonvulsive compound, on GABA metabolism. J. Neurochem., 16, 869-873.

Gottlicher M. et al., 2001. Valproic acid defines a novel class of HDAC inhibitors inducing differentiation of transformed cells. EMBO J., 20, 6969-6978.

Hargrave-Thomas E., Yu B. \& Reynisson J., 2012. Serendipity in anticancer drug discovery. World J. Clin. Oncol., 3, 1-6.

Harvey P.K., Bradford H.F. \& Davison A.N., 1975. The inhibitory effect of sodium n-dipropyl acetate on the degradative enzymes of the GABA shunt. FEBS Lett., 52, 251-254.

Hubaux R. et al., 2010. Preclinical evidence for a beneficial impact of valproate on the response of small cell lung cancer to first-line chemotherapy. Eur. J. Cancer, 46, 1724-1734.

Kishore P., Rajani Kumar V., Satyanarayana V. \& Krishna D.R., 2003. HPLC determination of valproic acid in human serum. Pharmazie, 58, 378-380.

Lezin A. et al., 2007. Histone deacetylase mediated transcriptional activation reduces proviral loads in HTLV-1 associated myelopathy/tropical spastic paraparesis patients. Blood, 110, 3722-3728.

Ligon B.L., 2004. Penicillin: its discovery and early development. Semin. Pediatr. Infect. Dis., 15, 52-57.

Loscher W., 1981. Valproate induced changes in GABA metabolism at the subcellular level. Biochem. Pharmacol., 30, 1364-1366.
Loscher W., 2002. Basic pharmacology of valproate: a review after 35 years of clinical use for the treatment of epilepsy. CNS Drugs, 16, 669-694.

Meunier H. et al., 1963. Pharmacodynamic properties of N-dipropylacetic acid. Thérapie, 18, 435-438.

Nau H., Hauck R.-S. \& Ehlers K., 1991. Valproic acidinduced neural tube defects in mouse and human: aspects of chirality, alternative drug development, pharmacokinetics and possible mechanisms. Pharmacol. Toxicol., 69, 310-321.

Navarrete A., Avula B., Choi Y.W. \& Khan I.A., 2006. Chemical fingerprinting of Valeriana species: simultaneous determination of valerenic acids, flavonoids, and phenylpropanoids using liquid chromatography with ultraviolet detection. J. AOAC Int ., 89, 8-15.

Pharmacopoeia, 2014. European Pharmacopoeia 2014 and Supplement 5.1-5.7. Strasbourg, France: Council of Europe.

Simler S., Randrianarisoa H., Lehmann A. \& Mandel P., 1968. Effects of di-n-propylacetate on audiogenic crises in mice. J. Physiol. (Paris), 60 (Suppl. 2), 547.

Smith K.A., 2012. Louis Pasteur, the father of immunology? Front. Immunol., 3, 68.

Upton R., 1999. Valerian root: Valeriana officinalis. Analytical, quality control, and therapeutic monograph. Santa Cruz, CA, USA: American Herbal Pharmacopoeia.

Vandermeers F. et al., 2009. Valproate, in combination with pemetrexed and cisplatin, provides additional efficacy to the treatment of malignant mesothelioma. Clin. Cancer Res., 15, 2818-2828.

World Health Organization, 1999. WHO monographs on selected medicinal plants. Geneva, Switzerland: World Health Organization.

(23 ref.) 